\title{
Rare But Life-Threatening Complication of Hydatid Disease
}

Nadir Fakat Hayati Tehdit Eden Bir Kist Hidatik Komplikasyonu

\author{
Fatih Karakaya', Çağdaş Kalkan¹, Melek Karakaya², Necati Örmeci \\ 1Department of Gastroenterology, Ankara University School of Medicine, Ankara, Turkey \\ 2Department of Internal Medicine, Ankara University School of Medicine, Ankara, Turkey
}

Cite this article as: Karakaya F, Kalkan Ç, Karakaya M, Örmeci N. Rare But Life-Threatening Complication of Hydatid Disease. Türkiye Parazitol Derg 2017; 41: 180-2.

\section{ABSTRACT}

Cystic echinococcosis is an infectious disease that is potentially associated with the biliary tract. Of thousand cases of hydatid cysts that were successfully treated by the Örmeci method, only two presented with cholangitis subsequent to the percutaneous treatment. These cases were treated with endoscopic retrograde cholangiopancreatography, and this study provides details regarding the clear fistulization of hydatid cysts into the biliary tract. Keywords: Örmeci method, cystic echinococcosis, cholangitis

Received: 21.09.2016

Accepted: 31.07 .2017

\section{ÖZ}

Kistik Ekinokokkozis safra yolları ile ilişkili olabilecek bir enfeksiyöz hastalıktır. Binden fazla hidatik kist hastası Örmeci metodu ile başarılı bir şekilde tedavi edildi, sadece iki olguda perkütan tedavi sonrası kolanjit gelişti. Bu olgular endoskopik retrograt kolanjiopankreatografi ile tedavi edildi ve bu yazı ile hidatik kistin biliyer fistülizasyonu net bir şekilde gösterlmiştir.

Anahtar Kelimeler: Örmeci method, cystic echinococcosis, cholangitis

Geliş Tarihi: 21.09.2016

Kabul Tarihi: 31.07.2017

\section{INTRODUCTION}

Cystic echinococcosis is an infectious disease that is caused by the parasite Echinococcus granulosus. Dogs and other canids are the main sources of these parasites. The disease is predominantly observed in the Middle East, Eastern Europe, Africa, Far East, Australia, New Zealand, and South America; it is prominent in areas with populations having a lower socioeconomic status (1). The following two percutaneous approaches are widely used for treating cystic echinococcosis: (a) puncture, aspiration, injection, and re-aspiration (PAIR) method and (b) Örmeci method. The Örmeci method involves injecting a mixture comprising two-thirds of pure alcohol and one-third of aetoxisclerol ( $1 \%$ polidocanol) into $2 \%$ of the cystic volume using a 22-gauge needle. The treatment of type CE3B hydatid cyst (WHO classification) (2) is contraindicated by the PAIR method. Those cysts can be treated by the Örmeci method (3). Percutaneous approaches for treating cystic echinococcosis have several advantages compared with surgical intervention. Although success rates are high for both therapeutic methods, percutaneous methods have the advantage in that they can be used on an outpatient basis and are associated with an absence of mortality, low morbidity, and reduced hospital stay. It has been occasionally observed that the hydatid cyst can rupture in the biliary duct or intrapleural or peritoneal space. Such a rupture results in obstructive jaundice and cholangitis. The latter can cause the development of life-threatening septicemia and hence should be immediately treated by endoscopic retrograde cholangiopancreatography $(\operatorname{ERCP})(3,4)$.

In this study, we present two cases wherein the hydatid cyst ruptured in the biliary ducts, and the patients required treatment by ERCP. A thorough literature review is also presented.

\section{CASE REPORT}

\section{CASE 1}

A 57-year-old male patient presented with pain and discomfort in the right upper quadrant. Abdominal ultrasonography (US) revealed the presence of type CE3B hydatid cyst, mea-

Address for Correspondence / Yazışma Adresi: Fatih Karakaya, E.mail: mfkarakaya@yahoo.com DOI: 10.5152/tpd.2017.5078

(C) Copyright 2017 Turkish Society for Parasitology - Available online at www.tparazitolderg.org

(O)Telif hakkı 2017 Türkiye Parazitoloji Derneği - Makale metnine www.tparazitolderg.org web sayfasından ulaşılabilir. 
suring $90 \times 77 \mathrm{~mm}$ in diameter, located in segment 6-7 of the liver. Laboratory test results of the patient were as follows: aspartate amino transferase (AST), $23 \mathrm{U} / \mathrm{L}$; alanine amino transferase (ALT), $23 \mathrm{U} / \mathrm{L}$; total bilirubin, $0.5 \mathrm{mg} / \mathrm{dL}$; direct bilirubin, $0.1 \mathrm{mg} / \mathrm{dL}$; gamma-glutamyl transferase (GGT), $27 \mathrm{U} / \mathrm{L}$; and alkaline phosphatase (ALP), $74 \mathrm{U} / \mathrm{L}$. The patient was successfully treated by the Örmeci method (2) and discharged after the treatment. Fifteen days after the percutaneous treatment, the patient was admitted to our emergency service with complaints of jaundice and pain in the right upper quadrant. Selected laboratory test results of the patient were as follows: AST, $125 \mathrm{U} / \mathrm{L} ; \mathrm{ALT}, 334 \mathrm{U} / \mathrm{L}$; total bilirubin, $6.3 \mathrm{mg} / \mathrm{dL}$; direct bilirubin, $4 \mathrm{mg} / \mathrm{dL} ; \mathrm{GGT}, 273 \mathrm{U} / \mathrm{L} ; \mathrm{ALP}, 149 \mathrm{U} / \mathrm{L}$; lipase, $685 \mathrm{U} / \mathrm{L}$; and C-reactive protein (CRP), $34 \mathrm{mg} / \mathrm{L}$. As the case was strongly suggestive of cholangitis, abdominal US was performed, which revealed that the biliary tract was dilated and that the diameter of the common bile duct had increased to 13 $\mathrm{mm}$. Filling defects were observed inside the common bile duct. All oral intake of the patient was stopped, and intravenous meropenem treatment was initiated. The patient underwent ERCP, in which the contents of the germinative layer of the hydatid cysts were removed by balloon sweeping (Video). Subsequent to this procedure, cholangitis was observed to regress. The final laboratory test results of the patient were as follows: AST, $19 \mathrm{U} / \mathrm{L} ; A L T$, $23 \mathrm{U} / \mathrm{L}$; total bilirubin, $1 \mathrm{mg} / \mathrm{dL}$; direct bilirubin, $0.4 \mathrm{mg} / \mathrm{dL}$; GGT, $136 \mathrm{U} / \mathrm{L} ; \mathrm{ALP}, 123 \mathrm{U} / \mathrm{L}$; and CRP, $25 \mathrm{mg} / \mathrm{L}$. During the follow-up visits of up to 16 months after the treatment, there was no recurrence of either the hydatid cyst or cholangitis, and the patient was concluded to be cured. Informed consent was obtained from patient before presentation.

\section{CASE 2}

A 64-year-old male patient presented with fullness in the right upper quadrant. Abdominal US revealed the presence of a Garby type 3B hydatid cyst (as per WHO guidelines), measuring $100 \times 89 \mathrm{~mm}$ in diameter, located in segment 7 of the liver. Laboratory test results of the patient were as follows: AST, $14 \mathrm{U} / \mathrm{L}$; $\mathrm{ALT}, 22 \mathrm{U} / \mathrm{L}$; total bilirubin, $1.2 \mathrm{mg} / \mathrm{dL}$; direct bilirubin, $0.6 \mathrm{mg} / \mathrm{dL}$; GGT, $78 \mathrm{U} / \mathrm{L}$; and ALP, $80 \mathrm{U} / \mathrm{L}$. The patient was successfully treated by the Örmeci method. Six days after the percutaneous treatment, the patient was admitted to our emergency service with complaints of abdominal pain and fever. Selected laboratory test results of the patient were as follows: AST, $47 \mathrm{U} / \mathrm{L} ; A L T, 65 \mathrm{U} / \mathrm{L}$; total bilirubin, $1.2 \mathrm{mg} / \mathrm{dL}$; direct bilirubin, $0.6 \mathrm{mg} / \mathrm{dL} ; \mathrm{GGT}, 211$ $\mathrm{U} / \mathrm{L} ; \mathrm{ALP}, 276 \mathrm{U} / \mathrm{L}$; and CRP, $265 \mathrm{mg} / \mathrm{L}$. Abdominal US revealed a cystic lesion, measuring $10 \mathrm{~cm}$ in diameter, located in the right lobe of the liver along with minimal prominence in the intrahepatic bile ducts. Intravenous piperacillin/tazobactam treatment was initiated. ERCP was performed, and the diagnosis of rupture of hydatid cyst in the biliary ducts and communication of the hydatid cyst with the bile ducts was confirmed (Figure 1). By balloon sweeping, the contents of the germinative layer of the hydatid cyst, located in the common bile duct, were removed. Five days after the treatment, selected laboratory test results of the patient were as follows: AST, $12 \mathrm{U} / \mathrm{L} ; A L T, 21 \mathrm{U} / \mathrm{L}$; total bilirubin, $0.4 \mathrm{mg} /$ $\mathrm{dL}$; direct bilirubin, $0.2 \mathrm{mg} / \mathrm{dL} ; \mathrm{GGT}, 240 \mathrm{U} / \mathrm{L} ; A L P, 136 \mathrm{U} / \mathrm{L}$; and CRP, $113 \mathrm{mg} / \mathrm{L}$. After 7 days, cholangitis was again observed in the patient, possibly because of the evacuation of some germinative membrane pieces into the common bile duct. The patient

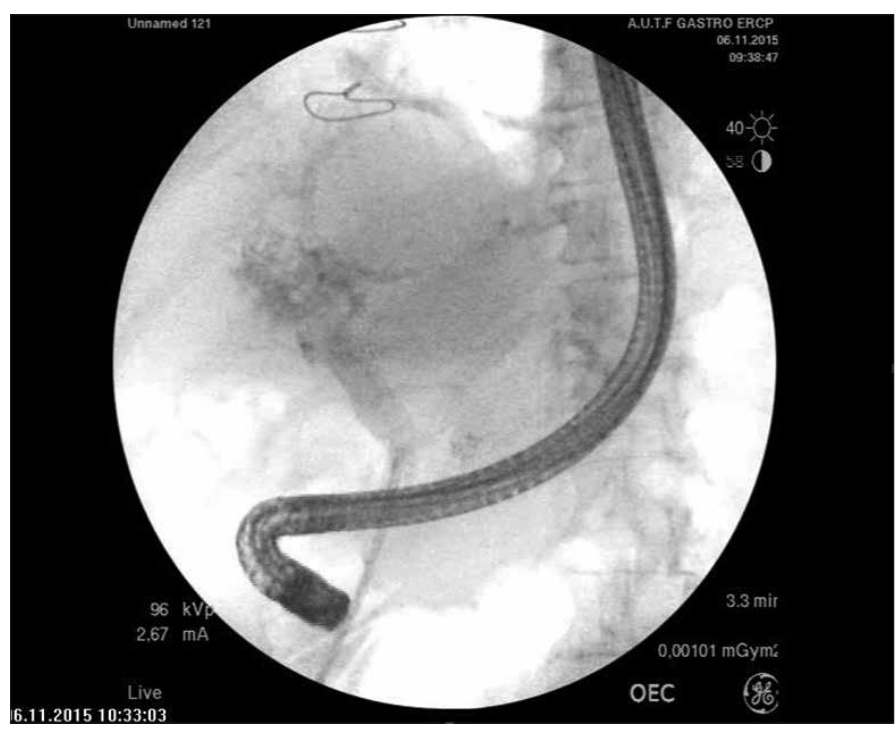

Figure 1. Fistulization of the hydatid cyst to the bile ducts

underwent surgery owing to the proximity of the hydatid cyst to the bile ducts. Subsequent to this surgical procedure, the patient was observed to be cured of the complaint. Informed consent was obtained from patient before presentation.

\section{DISCUSSION}

The hydatid cyst is an important public healthcare problem in endemic areas such as Eastern Europe and Mediterranean countries such as Turkey, South Africa, South America, Far East, and Australia. The indirect hemagglutination test is sensitive and can be used for the diagnosis. However, it has now been replaced by the enzyme immunoassay (EIA) for the initial screening of sera. Specific confirmation of reactivity can be obtained by the demonstration of specific echinococcal antigens using immunoblot assays. Eosinophilia is present in $<25 \%$ of infected individuals. Imaging methods such as ultrasonography, CT, and MRI are also used to diagnose hydatid cysts (5).

Hydatid cysts have the potential to develop complications such as the formation of fistulae between cysts and biliary ducts, rupture of the cyst and leakage of its contents in the biliary ducts, fistulization of the cyst into the pleural or peritoneal spaces or into structures located within the thoracic cavity, abscess formation because of secondary infections at the cyst site, fistulization of the cyst to the skin or gastrointestinal tract, and sudden death $(3,6)$. It is recommended that patients with such complications of hydatid disease should be treated by endoscopic or surgical methods.

Of the 980 patients who were treated by the Örmeci method, only two cysts ruptured in the biliary ducts. High intra-cystic pressure can occasionally cause hydatid cysts to spontaneously rupture in various cavities.

A meta-analysis of 21 studies was performed by Smego et al., which revealed that 34 (4.4\%) of 769 patients who presented with cystic echinococcosis were observed to have fistulae between the cyst and bile ducts; these patients were treated using the PAIR method (7). In contrast, of 980 patients with cystic echino- 
coccosis who were percutaneously treated using Örmeci method, only two showed fistulization of the cyst into the biliary duct with the eventual development of cholangitis (0.2\%).

Golemanov et al. reported that $8.9 \%$ of patients who presented with hydatid cysts of $\geq 10 \mathrm{~cm}$ in diameter developed fistulization when treated a second time by the PAIR method (8).

Type 3B hydatid cysts (WHO Classification) are contraindicated for the treatment by PAIR method. However, the Örmeci method can be successfully used for this type of hydatid cyst. The diameters of the cysts treated by our method were 10 and $9 \mathrm{~cm}$. When the diameter of the hydatid cyst is increased, the injected amount of pure alcohol and polidocanol into cyst is also increased without aspiration. Besides multipuncture percutaneous treatment can be require for type $3 \mathrm{~B}$ hydatid cyst so that multipuncture sides may be another reason for fistulization.

In a report, Borahma et al. reported that 16 patients presented with severe cholangitis subsequent to hydatid cysts. After endoscopic sphincterotomy, the fistulas between the bile ducts and hydatid cysts were healed in $80 \%$ of the patients (4). Cholangitis caused by a ruptured hydatid cyst can be successfully treated using endoscopic sphincterotomy. Hydatid cysts of $>9 \mathrm{~cm}$ in diameter and multipuncture of type CE3B cysts may have a risk for developing fistulae during the percutaneous treatment.

\section{CONCLUSION}

On the basis of the results presented herein, we recommend that patients with type CE3B hydatid cysts that are $>9 \mathrm{~cm}$ in diameter and/or cases of multipuncture percutaneous treatment, there is an increased risk for the occurrence of fistulization; therefore, type CE3B hydatid cysts should be closely followed up, and in the case of fistulization, the cysts should be immediately treated with endoscopic sphincterotomy.

Hasta Onamı: Yazılı hasta onamı bu çalışmaya katılan hastadan alınmıştır.

Hakem Değerlendirmesi: Dış bağımsız.

Yazar Katkıları: Fikir - F.K., N.Ö.; Tasarım - F.K., M.K.; Denetleme - N.Ö.; Kaynaklar - F.K., Ç.K.; Malzemeler - F.K., Ç.K., M.K., N.Ö.; Veri Toplanması ve/veya İşlemesi - F.K., Ç.K., M.K., N.Ö.; Analiz ve/veya Yorum - F.K., N.Ö.; Literatür Taraması - F.K., Ç.K., M.K., N.Ö.; Yazıyı Yazan - F.K., N.Ö.; Eleştirel İnceleme - F.K., Ç.K., M.K., N.Ö.

Çıkar Çatışması: Yazarlar çıkar çatışması bildirmemişlerdir.
Finansal Destek: Yazarlar bu çalışma için finansal destek almadıklarını beyan etmişlerdir.

Informed Consent: Written informed consent was obtained patient who participated in this study.

Peer-review: Externally peer-reviewed.

Author Contributions: Concept - F.K., N.Ö. Design - F.K., M.K.; Supervision - N.Ö.; Funding - F.K., Ç.K.; Materials - F.K., Ç.K., M.K., N.Ö.; Data Collection and/or Processing - F.K., Ç.K., M.K., N.Ö.; Analysis and/or Interpretation - F.K., N.Ö.; Literature Review - F.K., Ç.K., M.K., N.Ö.; Writing - F.K., N.Ö.; Critical Review - F.K., Ç.K., M.K., N.Ö.

Conflict of Interest: No conflict of interest was declared by the authors.

Financial Disclosure: The authors declared that this study has received no financial support.

Video 1. Removing germinative layer of the hydatid cysts by balloon sweeping

\section{REFERENCES}

1. Eckert J, Deplazes P. Biological, epidemiological, and clinical aspects of echinococcosis, a zoonosis of increasing concern. Clin Microbiol Rev 2004; 17:107-35. [CrossRef]

2. Giorgio A, Di Sarno A, de Stefano G, Liorre G, Farella N, Scognamiglio $U$, et al. Sonography and clinical outcome of viable hydatid liver cysts treated with double percutaneous aspiration and ethanol injection as first-line therapy: efficacy and long-term follow-up. AJR Am J Roentgenol 2009; 193: 186-92. [CrossRef]

3. Örmeci N. PAIR vs Örmeci technique for the treatment of hydatidcyst. Turk J Gastroenterol 2014; 25: 358-64. [CrossRef]

4. Borahma M, Afifi R, Benelbarhdadi I, Ajana FZ, Essamri W, Essaid A. Endoscopic retrograde cholangio pancreatography in ruptured liver hydatid cyst. Indian J Gastroenterol 2015; 34: 330-34. [CrossRef]

5. Akkaya H, Akkaya B, Gönülcü S. Hydatid Disease Involving Some Rare Sites in the Body Turkiye Parazitol Derg 2015; 39: 78-82. [CrossRef]

6. Dziri C, Haouet K, Fingerhut A. Treatment of hydatid cyst of the liver: where is the evidence? World J Surg 2004; 28: 731-6. [CrossRef]

7. Smego RA Jr, Bhatti S, Khaliq AA, Beg MA. Percutaneous aspiration-injection-reaspiration drainage plus albendazole or mebendazole for hepatic cystic echinococcosis: A meta-analysis. Clin Infect Dis 2003; 37: 1073-83. [CrossRef]

8. Golemanov B, Grigorov N, Mitova R, Genov J, Vuchev D, Tamarozzi $F$ et al. Efficacy and safety of PAIR for cystic echinococcosis: experience on a large series of patients from Bulgaria. Am J Trop Med Hyg 2011; 84: 48-51.[CrossRef] 